\title{
Management of Kidney Cancers in Urology Department of the Gabriel Toure University Hospital/Bamako
}

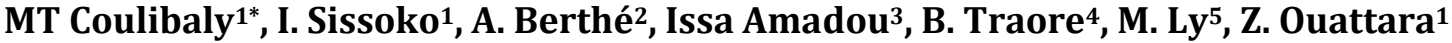 \\ ${ }^{1}$ Urology Department of CHU Gabriel Touré, Bamako, Mali \\ ${ }^{2}$ Urology Department of CHU Point G, Bamako, Mali \\ ${ }^{3}$ Pediatric Surgeon of CHU Gabriel Touré, Bamako, Mali \\ ${ }^{4}$ Urology Department of CSREF Commune II, Bamako, Mali \\ ${ }^{5}$ Medical Oncologist of CHU Luxembourg, Bamako, Mali \\ Email:*mamadoutc@yahoo.fr
}

How to cite this paper: Coulibaly, M., Sissoko, I., Berthé, A., Amadou, I., Traore, B., Ly, M. and Ouattara, Z. (2018) Management of Kidney Cancers in Urology Department of the Gabriel Toure University Hospital/Bamako. Surgical Science, 9, 183-188.

https://doi.org/10.4236/ss.2018.96021

Received: May 14, 2018

Accepted: June 12, 2018

Published: June 15, 2018

Copyright ( $) 2018$ by authors and Scientific Research Publishing Inc. This work is licensed under the Creative Commons Attribution-NonCommercial International License (CC BY-NC 4.0).

http://creativecommons.org/licenses/by-nc/4.0/

\section{(c) (i) (8) Open Access}

\begin{abstract}
Objective: to report our experience in the management of adult kidney cancer. Patients and Methods: This was a prospective and descriptive study, carried out in the Urology Department of Gabriel Touré University Hospital, during the period from January 1, 2001 to December 31, 2017 for a period of six years, interesting all the medical records of 24 adult patients diagnosed with kidney cancer. Results: During the study period, 24 patients met our inclusion criteria; the mean age was $48.23 \pm 8.02$ years with extreme ranging from 17 to 82 years. Most of our patients were female (58.3\%), and were referred or consulted for lumbar mass in $66.7 \%$ of cases. The average tumor size was $13.6 \pm 5.8 \mathrm{~cm}$ with extremes of 7.8 to $21.1 \mathrm{~cm}$. Management included total nephrectomy in $50 \%$ and total nephrectomy expanded in $50 \%$ of cases. The histological type found was renal cell carcinoma in 23 patients and papillary carcinoma in one patient. Conclusion: Kidney cancer is rare in our context, its clinical and histological characteristics remain the same for two decades. Its management is largely based on enlarged total nephrectomy.
\end{abstract}

\section{Keywords}

Kidney Cancer, Adult, Nephrectomy, Mali

\section{Introduction}

Kidney cancer is the third most common cancer of the urogenital tract, after those of the prostate and bladder. It accounts for $2 \%$ to $3 \%$ of adult solid cancers 
and is the sixth leading cause of cancer death in industrialized countries [1].

Its incidence is constantly increasing since the generalization of medical imaging examinations. It is estimated at 12.2 per 100,000 inhabitants in men and 5.7 per 100,000 in women in 150,000 new cases of renal parenchymal cancer discovered worldwide each year in 2006 [1]. The incidence of kidney cancer is up to ten times higher in North America and Europe than in Asia and Africa.

In Mali, there are very little data on adult kidney cancer specifically and most have been done before the advent of CT [2].

The purpose of our study is to report our experience in the management of adult kidney cancer.

\section{Patients and Methods}

This was a prospective and descriptive study, conducted in the Urology Department of Gabriel Touré University Hospital, during the period from January 1st, 2001 to December 31st, 2017 for a period of six years, interesting the medical files of 24 patients diagnosed with kidney cancer. As shown in Graph 1.

We included in this study, all major patients who consulted in the urology department of CHU Gabriel Toure and whose diagnosis of kidney cancer was retained after a clinical, paraclinical and histological examination during the study period.

Minor patients, tumors of the excretory tract and cases of kidney tumor without histological confirmation were excluded from the study.

The parameters studied were: age, sex, patient history, tumor size, length of stay, para-clinical examinations, histological type, etiologic and progressive treatment. The data has been entered and analyzed on the software Epi-info 3.5.1.

The follow-up of our patients has been made clinically and para-clinically at three months, six months and twelve months in close collaboration with our colleagues of medical oncology.

\section{Results}

During the study period, 24 patients met our inclusion criteria, the mean age was $48.23 \pm 8.02$ years with extremes ranging from 17 to 82 years. The most affected age group is between 21 - 30 years of age and 41 - 50 years old (Table 1). The most affected occupational group was housewives (37.5\%).

Most of our patients were female (58.3\%), and were referred or consulted for lumbar mass in $66.7 \%$ of cases. Clinical examination found lumbar contact in $66.7 \%$, and $12.5 \%$ of patients had an impaired general condition.

The required imaging examinations were first-line ultrasound in $100 \%$ of cases, followed by CT in $85.6 \%$ of cases.

The average tumor size was $13.6 \pm 5.8 \mathrm{~cm}$ with extremes of 7.8 to $21.1 \mathrm{~cm}$.

The extension assessment was made of thoraco-abdominopelvic CT, performed in $78.4 \%$ of patients, and found metastases in half of our patients (Figure $1)$. 
Table 1. Cases by age group.

\begin{tabular}{ccccc}
\hline Classe d'âge & Effectifs & Pourcentage & Pourcentage valide & Pourcentage cumulé \\
\hline $0-20$ & 3 & 12.5 & 12.5 & 12.5 \\
$21-30$ & 6 & 25 & 25 & 37.5 \\
$31-40$ & 1 & 4.2 & 4.2 & 41.7 \\
$41-50$ & 6 & 25 & 25 & 66.7 \\
$51-60$ & 5 & 20.8 & 20.8 & 87.5 \\
$61-70$ & 2 & 8.3 & 8.3 & 95.8 \\
81 et plus & 1 & 4.2 & 4.2 & 100 \\
Total & 24 & 100 & 100 & \\
\hline
\end{tabular}

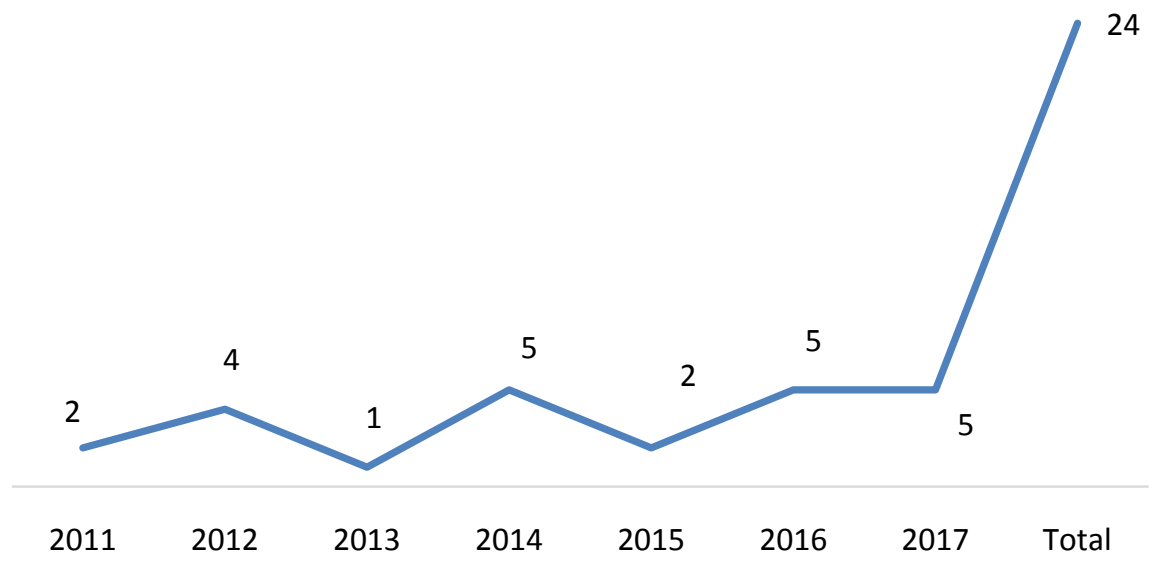

Graph 1. Cases by year.

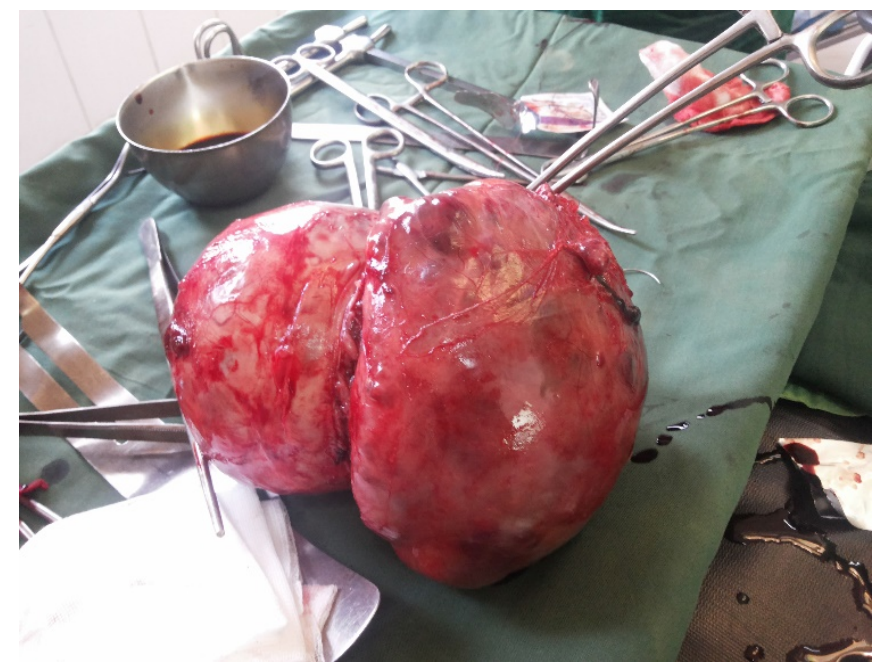

Figure 1. Image of a renal tumor after nephrectomy.

The left side was the predominant side and management included total nephrectomy in $50 \%$ and total nephrectomy enlarged in $50 \%$ of cases (Table 2, Figure 2). 
Table 2. Distribution according to treatment.

\begin{tabular}{rcc}
\hline Type de néphrectomie & Pourcentage \\
\hline Néphrectomie totale (simple) & 12 & 50 \\
Néphrectomie totale (élargie) & 12 & 50 \\
Total & 24 & 100 \\
\hline
\end{tabular}

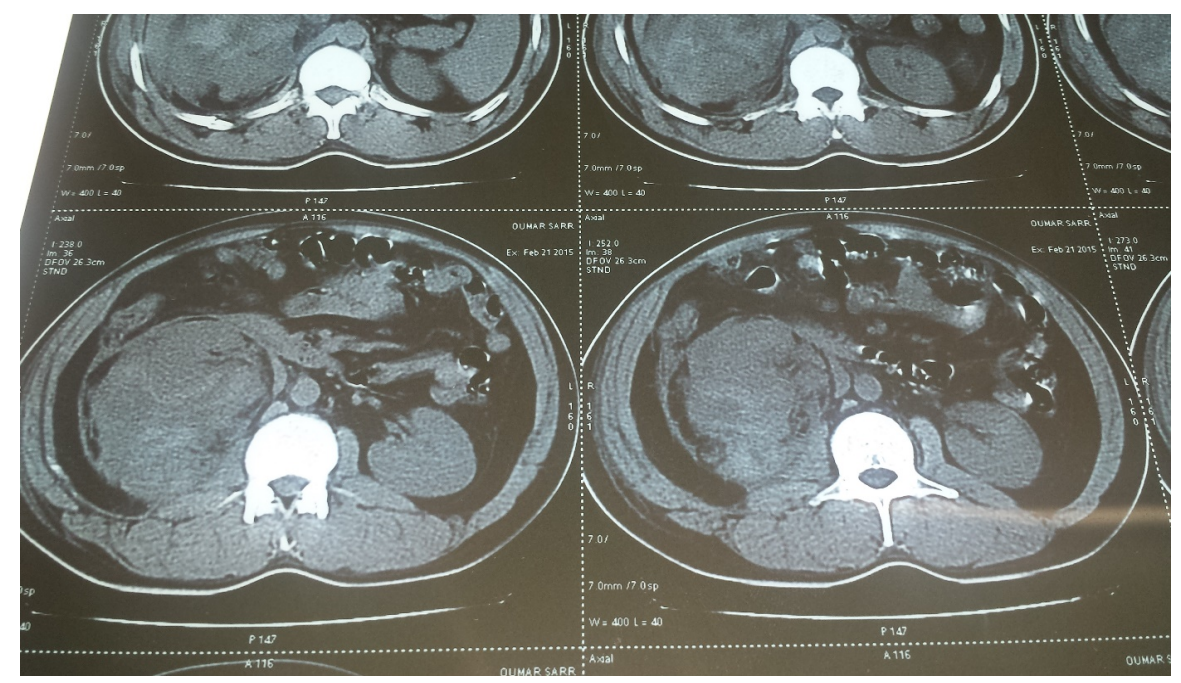

Figure 2. Image of a kidney cancer tumor.

Our patients were classified according to the TNM 2009 classification, and distributed as follows: $17 \%$ T1N0M0, 23\% T2N0M0, 60\% N+, M+

The histological type found was renal cell carcinoma in 23 patients and papillary carcinoma in one patient.

The immediate postoperative evolution was enamelled by the passage in intensive care of 2 patients including one case of death (Table 3 ).

The long-term evolution was clinical remission, no local recurrence at 3 and 6 months postoperatively.

The cases of metastases were sent to the medical oncology department.

\section{Discussion}

Kidney cancer remains a rare cancer by its frequency, so, over a period of six years, we have collected 24 cases of adult kidney cancer in our department, ie 4 cases per year. It represents $1.3 \%$ of urological cancers in our service. This rate is slightly higher than that of Ouattara et al. [2] in 1993 in the same country, which found 10 cases of kidney cancer in adults in 3 years, and that of B Fall et al. [3] who found 85 cases of cancer in 20 years in Senegal in 2010. This increase in the rate is related to the improvement of the technical plateau including imaging, but also to the early consultation of patients.

Our patients were young, most of whom were in the 21 - 30 age group, and 41 - 50 years old, with an average age of $48.23 \pm 8.02$ years, which is comparable to 
Table 3. Distrubition according to evolution.

\begin{tabular}{ccc}
\hline Evolution & Effectifs & Pourcentage \\
\hline Favorable & 22 & 91.7 \\
Transfert en réanimation & 2 & 8.3 \\
Total & 24 & 100 \\
\hline
\end{tabular}

that of TENGUE K et al. in Togo [4] and B Fall et al. [3] in Senegal with mean ages of $48.09 \pm 10$ years and 47 years respectively.

The sex ratio $(\mathrm{M} / \mathrm{F})$ was 0.71 for women in our study, compared with 0.88 for TENGUE K et al. [4] in Togo and 1.21 for B Fall et al. [3] in Senegal.

The lumbar mass was the most represented reason for consultation, but no case of hematuria was found in our series [1] [2] [3] [4].

Since the advent of imaging and its generalization in recent years, there has been an increasing increase in the frequency of kidney tumors [1]. Thus, we performed a renal ultrasound in all our patients and a computed tomography in $85.6 \%$ cases. The MRI recommended by the CCAFU (committee of cancer of the French Association of Urology) 2016/2018 [5] for cystic tumors and poorly characterized tumors by other imaging exams, was not used in our study due to lack of availability. B Fall et al. [3] in Senegal performed MRI in 1.3\% of patients.

The extension assessment found metastases in almost half of the cases, the preferred sites were notably pulmonary and hepatic. Most of these patients were subsequently referred to the Medical Oncology Department.

Enlarged total nephrectomy was performed in all our patients whose operative follow-up was good in the majority of cases, the histological type found was a clear cell carcinoma in all cases and a case of papillary carcinoma. It is the standard treatment for kidney tumors that are extirpable and over $7 \mathrm{~cm}$ in size [5] [6] [7]. None of our patients were theoretically eligible for partial nephrectomy, and no case of renal biopsy was performed.

Postoperative follow-up of metastatic forms in oncology was done by alpha interferon. Anti-angiogenics and immunotherapy were not used due to lack of availability and financial means.

\section{Conclusion}

Kidney cancer is rare in our context, its clinical and histological characteristics remain the same for two decades. Its management is largely based on enlarged total nephrectomy.

\section{Declaration of Interest}

The authors declare that they have no conflicts of interest in relation to this article.

\section{References}

[1] Cohen, J., et al. (2017) Le cancer du rein sporadique du sujet jeune: étude des 
particularités cliniques et anatomopathologiques d'une cohorte bicentrique. Progrès en Urologie, 28, 94-106. https://doi.org/10.1016/j.purol.2017.10.007

[2] Ouattara, K., et al. (1993) Les tumeurs du rein dans la pratique de l'urologue au Mali (A propos de 17 cas). Médecine d'Afrique Noire, 40, 253-256.

[3] Tengue, K., et al. (2015) Le cancer du rein de l'adulte au Togo: fréquence, diagnostic, traitement et évolution. Uro'Andro, 1, 177-182.

[4] Fall, B., et al. (2011) Le cancer du rein de l'adulte au Sénégal: aspects épidémiologiques et cliniques actuels et évolution du profil sur les deux dernières décennies. Progrès en Urologie, 21, 521-526.

https://doi.org/10.1016/j.purol.2011.02.013

[5] Bensalah, K., et al. (2016) Recommandations en onco-urologie 2016-2018 du CCAFU: Cancer du rein. Progrès en Urologie, 27, S27-S52. https://doi.org/10.1016/S1166-7087(16)30702-3

[6] Darré, T., et al. (2014) Cancers urologiques au Togo: profil histoépidémiologique à propos de 678 cas. Journal Africain du Cancer, 6, 27-31. https://doi.org/10.1007/s12558-013-0296-3

[7] Ouattara, A., et al. (2012) Épidémiologie des cancers urologiques au Centre national hospitalier universitaire Hubert Koutoukou Maga Cotonou, Bénin. Analyse d'une série hospitalière de 158 cas. Progrès en Urologie, 22, 261-265.

https://doi.org/10.1016/j.purol.2011.12.003 